\title{
TEXTO HOMENAGEM: OS SOFRIMENTOS DO JOVEM ALENCAR
}

http://dx.doi.org/10.11606/issn.2237-1184.v0i34p32-47

Wilton José Marques ${ }^{\mathrm{I}}$

\section{RESUMO}

Este artigo trata de um aspecto pouco conhecido da produção literária de José de Alencar, isto é, sua poesia. Nesse sentido, discute alguns poemas e um fragmento de crônica inédita que expressam sofrimentos amorosos motivados por uma malograda relação amorosa de juventude.

\section{ABSTRACT}

This article deals with a little-known aspect of José de Alencar's literary production, that is, his poetry. In this sense, he discusses some poems and a fragment of an unprecedented chronicle that express loving sufferings motivated by an unsuccessful youth love relationship.

\section{PALAVRAS-CHAVE:}

José de Alencar; Poesia; Poemas de amor; Crônica inédita

\section{KEYWORDS}

José de Alencar; Poetry; Love poems; Unprecedented chronicle.

I Universidade Federal de São Carlos, São Carlos, São Paulo, Brasil. 
Para Eduardo Vieira Martins, amigo de longa data e fino leitor de José de Alencar.

(Valeu, querido!)

Não me dão uma esperança

E nem m'a deixam perder. José de Alencar, "Ao correr dos olhos"

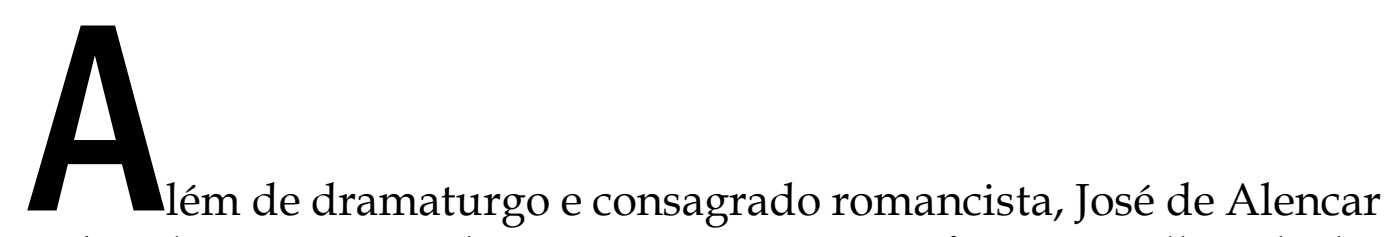
- cuja obra literária, notadamente a romanesca, franqueou-lhe, de há muito, um lugar definitivo na tradição literária brasileira - também foi poeta. Aliás, diga-se de passagem, que tal faceta alencariana é pouca (ou quase nada) explorada pela crítica. De todo modo, embora os poemas, tanto os líricos quanto a inconclusa tentativa épica de Os filhos de Tupã, não sejam muitos, foi justamente à poesia que recorreu para, como bom romântico, expressar seus sofrimentos amorosos, sobretudo os decorrentes de um fracassado caso de amor na juventude. Nessa mesma direção, biógrafos do autor afirmam que, em algum instante ao longo do período em que redigia os folhetins de Ao correr da pena para o Correio Mercantil, José de Alencar teria se apaixonado por uma jovem aristocrata, Francisca Calmon Nogueira Vale da Gama (cf. MENEZES, 1977, p. 73-74; NETO, 2006, p. 86-87, 105-110; VIANA FILHO, 2008, p. 67-68). A moça era filha do rico fazendeiro Nicolau Antônio Nogueira Vale da Gama, veador da Imperatriz e, posteriormente, camarista e mordomo de D. Pedro II. Além disso, o futuro Visconde Nogueira da Gama, com trânsito livre pelos corredores e pelos segredos mais íntimos do Paço imperial, ${ }^{2}$ também ocuparia a presidência do Cassino Fluminense. Entretanto, antes mesmo de se ater ao caso amoroso que motivou os poemas e, ao que tudo indica, o fragmento

\footnotetext{
${ }^{2}$ Amigo de confiança de Pedro II, o Visconde Nogueira da Gama, em Minhas memórias, transcreve, por exemplo, o trecho de uma carta do Imperador brasileiro ao então Regente de Portugal. Nela, referindo a Gama, Pedro II afirma: "[...] tenho-o também em conta de amigo, e merece-me toda confiança: para ele, não está sempre presenta a majestade, e há muito tempo que me conhece como homem também. [...]. Podes conversar com toda franqueza com o Nicolau a meu respeito, pois sempre encontrarás nele a mesma circunspecção e critério; é inteligente" (GAMA, 1893, p. 24).
} 
de uma crônica inédita, é preciso, ainda que brevemente, entender o início da atividade jornalística de Alencar nas páginas do Correio Mercantil.

\section{O novo folhetinista e o jornal liberal}

A rápida passagem do então jovem advogado, filho primogênito do velho e liberal senador Alencar, pelo jornal Correio Mercantil aconteceu por convite direto de Francisco Otaviano, que fora seu contemporâneo na Faculdade de Direito em São Paulo e dono da biblioteca de "maior cabedal" a que o aspirante a literato tivera, pela primeira vez, acesso às obras completas de Balzac, como relembraria mais tarde no relato biográfico de Como e porque sou romancista:

Uma das livrarias, a que maior cabedal trazia à nossa comum biblioteca, era a de Francisco Otaviano, [...]. Meu companheiro de casa era dos amigos de Otaviano, e estava no direito de usufruir sua opulência literária. Foi assim que um dia vi pela primeira vez o volume das obras completas de Balzac, [...]. Tendo meu companheiro concluído a leitura de Balzac, a instâncias minhas, passou-me o volume, [...]. Encerrei-me com o livro, e preparei-me para a luta. Escolhido o mais breve dos romances, armei-me de dicionário, e tropeçando a cada instante, buscando o significado de palavra em palavra, tornando atrás para reatar o fio da oração, arquei sem esmorecer com a ímproba tarefa. (ALENCAR, 1893, p. 28-30)

Francisco Otaviano - primeiro escritor a popularizar o gênero folhetim na imprensa brasileira ao combinar leveza de estilo e variedade de assuntos e que, inclusive, já havia indicado o jovem advogado para substituí-lo na coluna A Semana que manteve no Jornal do Comércio, entre 1852 e $1854^{3}$ - fez novo convite a José de Alencar agora para ocupar, aos domingos, um dos espaços nobres do Correio Mercantil, ou seja, o rodapé da primeira página, como um dos responsáveis - ao lado, de início, de Manuel Antônio de Almeida ("A."), Henrique Cesar Muzzio ("M.") e do próprio Otaviano ("FO." ou "O.") - pela redação da "Revista Semanal" das Páginas Menores, nova seção criada pela folha liberal em substituição à temida Pacotilha. ${ }^{4}$ A participação de Alencar, que sempre assinava seus

\footnotetext{
${ }^{3}$ Como explica o crítico João Roberto Faria, "entre os estudiosos das relações entre jornalismo e literatura no Brasil do século XIX, parece haver consenso em torno do nome de Francisco Otaviano como o primeiro a cultivar entre nós o folhetim caracterizado pela leveza de estilo e variedade de assunto. Com a seção intitulada "A Semana", que manteve entre 1852 e 1854, no Jornal do Comércio, ele foi o verdadeiro criador desse gênero no Brasil, segundo a opinião abalizada de Alceu Amoroso Lima" (ALENCAR, 2004, p. XVII).

${ }^{4}$ Circulando entre 9 de fevereiro de 1851 e 30 de junho de 1854, a Pacotilha, cujos textos tinham visada irônico-crítica, era o próprio jornal aos domingos e tem sua origem explicada pelo
} 
folhetins como "Al.", aconteceu entre os meses de setembro de 1854 e julho de 1855. Contudo, já em outubro daquele primeiro ano, em função da imediata e positiva receptividade dos leitores, a sua coluna, batizada de Ao correr da pena, passou a ser literalmente as Páginas Menores. Em carta aberta, publicada na Gazeta de Notícias, exatos onze dias após a morte do escritor cearense na manhã de 12 de dezembro de 1877, Otaviano narrou em detalhes como, de fato, acontecera a entrada de Alencar para a redação do Correio Mercantil:

Comunicando à direção daquele jornal [Jornal do Comércio] a necessidade em que me via de separar-me, fui intimado, como é cortesia na despedida dos ministros, para indicar o meu sucessor.

- José de Alencar, respondi sem hesitação.

Os diretores do Jornal não demonstraram nesse dia o tino que bem os encaminhava sempre.

[...] Do meu conselho se lembraram os diretores do Jornal; já era tarde. Eu estava constituído em centro do partido [liberal], redator principal do [Correio] Mercantil e cabeça de família. [...] Reconhecera a necessidade de ter Alencar a meu lado. Ele, cedendo a um sentimento que o honra, preferiu-me dar-me o seu concurso a alistar-se na turma dos meus competidores. (GAZETA DE NOTÍ́CIAS, 1877, p. 1)

Dessa forma, o consequente início da fama literária de José de Alencar, tanto na esteira do caminho aberto por Francisco Otaviano quanto em função de seu próprio estilo de escrita, deve mesmo ser atribuído ao evidente sucesso de público alcançado pelos folhetins de Ao correr da pena. Machado de Assis, corroborando posteriormente a fama do cronista num prefácio escrito para uma edição especial (e malograda) de O Guarani, afirmaria:

Os primeiros ensaios fê-los no Correio Mercantil, em 1853 [sic.], onde substituiu Francisco Otaviano na crônica. Curto era o espaço, pouca a matéria; mas a imaginação de Alencar supria e alargava as coisas, e com o seu pó de ouro borrifava as vulgaridades da semana. A vida fluminense era então outra, mais concentrada, menos ruidosa. O mundo ainda não nos falava todos os dias pelo telégrafo, nem a Europa nos mandava duas ou três vezes por semana, às braçadas, os seus jornais (ASSIS, 1994, p. 922-3).

acirramento dos entraves políticos com os conservadores que, naquele momento, estavam no poder. Com a articulação da Conciliação partidária, que em linhas gerais abria a possibilidade de incorporação de alguns membros moderados do Partido Liberal ao Gabinete Conservador, liderado pelo Marques de Paraná, o Correio Mercantil, que defendia a política conciliatória, resolveu acabar com a Pacotilha, substituindo-a pela nova seção Páginas Menores, em 9 de julho de 1854 (cf. AlENCAR, 2017, p. 10-5). 
Os folhetins alencarianos, abusando, e muito, da moda do trocadilho que, naquele momento, reinava nos jornais da corte, tratavam - como era de se esperar - dos mais variados assuntos da semana. Como explica Brito Broca, "a condição essencial para ser um bom folhetinista na época era frequentar os salões, os teatros e as galerias da Câmara e do Senado" (ALENCAR, 1960, p. 632). E ainda, nesse mesmo sentido, o crítico paulista complementou:

Os folhetins giravam frequentemente em torno de três assuntos que polarizavam o interesse e as atenções da sociedade brasileira do Segundo Reinado: o mundanismo (bailes, festas, recepções), a vida teatral (principalmente os espetáculos líricos) e a política (a eterna torcida provocada pelo revezamento dos partidos e a queda dos ministérios) (IDEM, ibidem).

\section{O surgimento da "estrela suave"}

Pois bem, ao também frequentar, agora por dever de ofício, o mundanismo do requintado Cassino Fluminense - "o centro principal dos divertimentos sociais", onde "se formavam e se desfaziam amizades, se intrigavam políticas, se ensaiavam namoros e se assentavam casamentos" (LYRA, 1977, p. 31) - o novo folhetinista do Correio Mercantil não demorou muito a encontrar a "sua" estrela. No folhetim de $1^{\circ}$ de outubro de 1854, escrevendo justamente a propósito de um recente baile no Cassino, "a noite que eu esperava ansiosamente", José de Alencar alertou os leitores que, na falta de folhetim no dia seguinte, deveriam focar suas atenções "na elegância das senhoras [e] na sociedade escolhida que aí se reuniu". Em meio a essa e outras reflexões e com linguagem beirando o poético, ainda revelou:

[...] há mulheres que são verdadeiras rosas, e que por isso têm para aqueles que se chegam um perfume e um espinho ao mesmo tempo.

Também devia de ver, como eu, surgir naquela noite uma estrela suave a deslizar docemente num céu azul. Era uma verdadeira estrela, [...], brilhando no céu; porque o céu é a pátria da candura e da inocência.

[...] uma estrela é tudo que há de mais puro e de mais casto no mundo (ALENCAR, 2004, p. 41-2).

No mês seguinte, em 5 de novembro, referiu-se a outro baile no mesmo Cassino, mas que, "se para alguns as horas correram deliciosamente", para outros, incluindo, é claro, o próprio folhetinista, "nem o céu esteve azul, nem luziu a estrela", já que a "sua" estrela não havia comparecido, e, por isso, não deixou de também lamentar que "as 
nuvens encobriram-na". Ao lembrar que "a vida foi durante essas horas não o sonho de uma sombra, mas a sombra de um nome ou de letra", tentou acalmar a si e, sobretudo, a curiosidade dos leitores "por saber que nome e que letra era esta que me incomodava tão seriamente, a ponto de fazer-me sonhar com ela no meio do baile. O nome não thes direi, mas a letra é um C" (IDEM, ibidem, p. 89). A letra seria uma possível alusão à Chiquinha Nogueira da Gama? Possivelmente. Aliás, algo denunciando que aquela paixão do folhetinista era de conhecimento público, ao menos dos membros da restrita "boa sociedade", Joaquim Nabuco - que mais tarde se envolveria numa polêmica literária com o próprio Alencar pelas páginas do jornal $O \mathrm{Globo}^{5}$-, ao aludir às concorridas reuniões sociais em sua casa, onde sempre estreavam as principais "belezas das províncias", afirmaria sem quaisquer meias palavras que, entre elas, estava "a filha de Nogueira da Gama, futura condessa de Penamacor, incensada por José de Alencar" (NABUCO, 1997, p. 1108).

De todo modo, a relação amorosa (ou talvez o desejo de) não foi adiante, seja por desinteresse e/ou, o que seria pior, por mero desprezo de Chiquinha, seja pela proibição familiar do próprio Visconde Nogueira da Gama, que, por pertencer à nata da aristocracia brasileira e, mais importante, ao círculo íntimo do Imperador, que o tinha como amigo, preferiu, como mencionou Nabuco, casá-la com um membro da nobreza portuguesa, o $3^{\circ}$ Conde de Penamacor, António Maria de Saldanha Albuquerque e Castro. ${ }^{6}$

No folhetim de 18 de março de 1855, um dia após o embarque da jovem e de seus pais para a Europa, ${ }^{7}$ um Alencar melancólico escreveria que "a dor, disse Lamartine, remoça o homem, dá-lhe nova força, novo vigor. Tu fais l'homme, ô douleur!", para, em seguida, ao comentar que "a enfermidade tem um quer que seja de viagens", acrescentar:

Talvez seja por esta semelhança que se dá a coincidência de cair no mesmo tempo a quadra das moléstias e das viagens. ${ }^{8}$ Tudo

\footnotetext{
${ }^{5}$ Para a polêmica entre Alencar e Nabuco, ver Martins (2010, p. 15-32).

${ }^{6}$ Nas Minha memórias, o Visconde Nogueira da Gama, referindo-se à segunda viagem a Portugal (1861-1862), observou: "Presos na capital portuguesa pelos obséquios e instâncias de nossos amigos, só dali pude partir com minha mulher, nossa segunda filha, de 6 anos de idade, e seu irmão recém chegado de suas longas viagens por quase todos os países da Europa, em outubro de 1862, deixando ali a nossa primeira filha [Francisca] casada com António Maria de Saldanha Albuquerque e Castro, filho primogênito e herdeiro dos Condes de Penamacor" (GAMA, 1893, p. 178-9).

${ }^{7}$ O Correio Mercantil, na sua primeira página, informava nas "Notícias diversas" que partiu hoje, 17 de março de 1855, para Lisboa: o "camarista N. A. N. Vale da Gama, sua senhora e uma filha [Francisca]". (CORREIO MERCANTIL, 1855, p. 1)

${ }^{8}$ Por curiosa coincidência, no relato da referida primeira viagem à Europa, o Visconde Nogueira da Gama, informa que "para minha filha não foram estes os únicos incômodos [enjoos do mar]:
} 
parte, tudo vai mar em fora, ver novos climas, correr terras, para ter na volta o que contar.

Queixam-se por aí que tudo vai para a exposição de Paris, menos os nossos produtos. Quem sabe? Talvez que a par da Estrela do Sul apareçam na exposição muitos outros produtos brasileiros, muitas raridades dignas de menção (ALENCAR, 2004, p. 248-9).

A "Estrela do Sul", que foi "mar em fora", seria outra possível menção à Francisca Nogueira da Gama? Apesar de ser difícil provar, tudo indica que sim. Em outro folhetim, de 13 de maio de 1855, Alencar rememoraria - "Lembras-te do Cassino?" - com alguma nostalgia o primeiro baile em que encontrara a "estrela suave". Agora, no entanto, em nova metáfora, sugeriu que a amada era uma "daquelas flores" que, "levadas pelas brisas do mar, lá se foram perfumar outros salões":

O lindo baile já não é aquela brilhante reunião de outros tempos, onde se viam agrupadas como flores de uma grinalda todas as moças bonitas desta terra.

Tudo passa; algumas daquelas flores, levadas pelas brisas do mar, lá se foram perfumar outros salões; muitas brilham aos raios de outro sol, e poucas ainda aí vão talvez unicamente para sentirem as reminiscências do passado. (Idem, ibidem, p. 328-9)

\section{Sofrimentos e desprezos: poemas à estrela suave}

Para os autores românticos, as desilusões do amor sempre acabavam em literatura, e o caso de José de Alencar não seria, nem de longe, diferente. ${ }^{9}$ Em dois dos oito folhetins de Ao correr da pena no Correio Mercantil, ${ }^{10}$ excluídos da primeira edição em livro, e reunidos sob os cuidados do Dr. José Maria Vaz Pinto Coelho em 1874 (Cf. AlENCAR, 1874), mas, ao que tudo indica, com interferência direta do próprio Alencar na seleção dos textos, ${ }^{11}$ aparecem dois significativos poemas que muito provavelmente teriam sido motivados pela paixão por Francisca Calmon Nogueira Vale da Gama, ou melhor, pela interrupção.

No primeiro folhetim, de 28 de janeiro de 1855, descobre-se que, entremeado aos diversos fatos ocorridos e comentados naquela semana,

\footnotetext{
apareceram sarampos a bordo, logo que saímos do Rio de Janeiro" e, para sua preocupação, "foi ela [Francisca] a última pessoa que os teve". (GAMA, 1893, p. 13)

9 Escrevendo sobre "o namoro de José de Alencar", Wanderley Pinho chega, inclusive, a conjecturar que Emília de Diva e Aurélia Camargo de Senhora teriam sido de alguma forma baseadas em Francisca Nogueira da Gama (Cf. PINHO, 1942, p. 141-150).

${ }^{10}$ Quando José de Alencar assumiu a redação do Diário do Rio de Janeiro, em outubro de 1855, ainda publicaria, conservando o nome de Ao correr da pena, mais sete folhetins, localizados e coligidos, em 1956, por Francisco de Assis Barbosa (Cf. AlENCAR, 1956).

${ }^{11}$ Para as possíveis razões das exclusões dos folhetins alencarianos na edição em livro, ver: Alencar (2017, p. 9-84).
} 
José de Alencar publicou o poema - "Ao correr dos olhos" - que, por sua vez, é um dolorido lamento pela não mais correspondência amorosa dos "olhos negros" da amada, que, para desgosto do poeta, "Andam sempre me enganando". Inclusive, o referido poema era antecedido pela seguinte explicação: "quero aproveitar a ocasião para dar-vos uns versinhos muito simples, que foram escritos há cerca de dois meses numa bela noite límpida e estrelada, e num momento de desfastio". Ou seja, ao enfatizar que foram simbolicamente escritos numa bela noite límpida e estrelada, Alencar explicitava, mesmo que de modo cifrado, a quem, na verdade, os versos se endereçavam, complementando sua explicação que "não foram feitos ao correr da pena, como podeis pensar, mas...." (2017, p. 103):

\section{Ao correr dos olhos}

Eu tenho nuns olhos negros

Desta minha alma o condão;

É por eles que ainda vivo,

E que morro de paixão.

São negros, negros, tão lindos,

Porém que maus que eles são!

Muito maus! Nunca me dizem

O que bem sabem dizer;

Não me dão uma esperança

E nem $\mathrm{m}^{\prime}$ a deixam perder.

Andam sempre me enganando,

Têm garbo em ver-me sofrer.

Por mais terno que os suplique

Não se condoem de mim;

Às vezes fitam-me a furto,

Porém nunca dizem sim.

Ah! Olhos negros tão maus

Nunca vi outros assim!

Não quero mais esses olhos;

Amo agora umas estrelas

Que entendem o meu silêncio

E me sorriem tão belas,

Que quando me sinto triste

Espero a noite p'ra vê-las.

(Idem, ibidem, p. 103-104)

Se, por um lado, os olhos negros e "muitos maus" da amada, que, paradoxalmente, "não me dão uma esperança/ E nem m'a deixam perder", levaram o eu lírico a não os querer mais; por outro, Alencar, na continuidade do folhetim, pareceu querer discutir, por sua conta, como os interesses financeiros afetavam as relações amorosas. Tanto que, no trecho 
seguinte ao poema, apresentou aos leitores a igualmente significativa pergunta: "Que vale o dinheiro para a mulher que amais?" Pode-se dizer que a ironia por traz da pergunta está no fato de ter sido respondida por uma inusitada "moeda de vinte mil réis", que insistia em desdenhar das "risonhas ficções do espírito". Para o folhetinista,

Uma moeda de vinte mil réis, por exemplo, quando tine, murmura docemente ao vosso ouvido. "Comigo tu podes ir passar um dia no Jardim, cear à larga com um amigo, ou comprar um bilhete de loteria em que talvez tires a sorte grande. Vinte contos! Com isso já podes te apresentar no mundo, e fazer algum casamento rico, ou mesmo possuíres a mulher que desejas. Olha! Eu te dou tudo isto".

Esse canto de sereia vos embriaga. Se ainda tendes no coração esse perfume d'alma, essa crença poética do verdadeiro sentimento, resistis ao encanto. Que vale o dinheiro para a mulher que amais? Não tendes n'alma tesouros de tanta dedicação, de tão grande afeto, mil vezes mais preciosos do que todos os tesouros do mundo?

Mas enquanto vos embalais nestas risonhas ficções do vosso espírito, a moedinha vos lança um reflexo dourado, tine de novo, e vos diz ainda mais docemente do que da primeira vez. "Não acredites nessas ilusões dos poetas. Só eu é que te posso dar a verdadeira felicidade. Tu cuidas que uma mulher te compreende? Dize-lhe uma palavra, e ela te enviará com sobrescrito ao pai ou ao tutor, ao qual a sociedade incumbiu, como procurador bastante, a gerência e administração desse patrimônio da família".

Por fim fareis como os outros, como todo o mundo. Não resistis mais; deixais que a torrente vos leve; e começais essa luta tenaz da fortuna, esse suplício de Tântalo de que já vos falei, e que acaba um dia por um ceticismo cruel que nega tudo, porque nasce do vácuo imenso da própria existência. (Idem, ibidem, p. 104-105)

Diante dos evidente indícios, pode-se conjecturar que o poema dos "olhos negros" e a "resposta" da moedinha de "reflexo dourado" já seriam, na verdade, uma espécie de resposta pública de Alencar, o primeiro remetendo ao ambíguo desprezo de Francisca e, a segunda, ao impedimento social dessa relação, já que, nem de longe, o autor romântico possuía posição social elevada ou, principalmente, "fortuna" compatível com os desejos e as expectativas da família aristocrata.

Aliás, no posterior desenvolvimento do projeto romanesco alencariano, e mais notadamente dos chamados romances urbanos, é possível perceber, segundo a análise esclarecedora de Valéria De Marco, a existência de um traço comum que os diferencia dos demais, isto é, a presença do dinheiro: 
[...] como mediador das relações entre as personagens, como elemento de conflito que deve ser contornado para chegar à realização de um sonho romântico ou à desilusão perante o caráter implacável dessa ordem social metálica. No mercado da corte, Aurélia (Senhora) dispõe-se a gastar sua fortuna para comprar Seixas; Emília (Diva) ainda estonteada procurando um marido que não seja movido pelo ouro; Guida e Ricardo (Sonhos D'Ouro) ficam separados por muito tempo até que o jovem bacharel consiga estabelecer-se para não se colocar mais como subalterno do velho Soares, e Paulo e Lúcia (Luciola) não podem casar-se, já que ela se mantinha pela venda de seu corpo". (DE MARCO, 1986, p. 72)

O segundo folhetim de 18 de fevereiro de 1855 - que tematiza, já que "o mundo é um grande baile mascarado", a suposta visita de um crítico Pierrô aos principais bailes de carnaval daquele ano (ALENCAR, 2017, p 127 e 129) - é rematado por outro poema de mesmo tema. Inclusive, ao apresentá-lo, Alencar insinuou desconhecer sua autoria - "Aí vão os versos. Não são meus, e nem vos sei dizer o autor, o que, estou certo, pouco vos interessa" (IDEM, ibidem, p. 135) -, mas que, quando republicado na Obra completa, com o detalhe de faltar a última estrofe da versão em folhetim, reapareceria com o título de "Jura" e com modificações pontuais (cf. ALENCAR, 1960, p. 623). De maneira geral, o eu lírico alencariano simplesmente renunciava ao amor da dama, que, entre outros tantos atributos, possuía indefectíveis "grandes olhos negros que fascinam":

Ainda és bela! No teu lábio altivo

Desfolha amor um lúbrico sorriso,

Dos grandes olhos negros que fascinam

Prometes n'um volver o paraíso.

Mas que importa? Para mim és uma estátua,

Legenda triste de infeliz passado,

Ou a sombra erradia de minha alma

Extinta por um dia haver-te amado.

Pode a teus pés curvar-se o mundo inteiro,

Podem render-te os homens vassalagem,

Que eu contemplo de longe sobranceiro

$\mathrm{D}^{\prime}$ uma mulher que amei a fria imagem.

Talvez um dia quando não restarem Nem vestígios daquele santo amor,

Eu venha, como os outros, já sem crença

Revelar-te o mistério d'uma dor.

Assim de longe terra o peregrino

Se volta à doce pátria que perdera, 
Ajoelha ante a lousa de seus pais Nas ruínas da casa onde nascera.

(ALENCAR, 2017, p. 135-6)

No poema, apesar de salientar de antemão, por um lado, a beleza da amada com seus "grandes olhos negros que fascinam" a prometerem "n'um volver o paraíso", e, de outro, o lugar social elevado ocupado pela mesma na sociedade - "Pode a teus pés curvar-se o mundo inteiro,/ Podem render-te os homens vassalagem" -, o eu lírico, de maneira incisiva e agora a reconhecendo como uma estátua, "legenda triste de infeliz passado", carregava consigo apenas e tão somente "os vestígios daquele santo amor" e "o mistério d'uma dor". Sem qualquer menção a quem o poema se referia ou ao fato de que saíra inicialmente neste folhetim de $A o$ Correr da pena, o crítico Araripe Júnior - que talvez nem soubesse ou, ao contrário, apenas tenha preferido omitir tais informações -, além de reproduzir o mesmo poema em nota de rodapé, afirmou que seguramente nessa época a vaidade de Alencar:

[...] passou pelas primeiras provações. Correm mesmo, por aí alguns versos vigorosos, cheios de indignação, que transpiram todo o fel que políticos ou não políticos derramaram-lhe na alma. Semelhantes versos revelam a existência de decepções que um moço de talento, e já festejado, não tolera sem protesto. (ARARIPE JÚNIOR, 1953, p. 181-2)

\section{A crônica interrompida e a vingança final}

Obviamente, é impossível saber por quanto tempo as inevitáveis amarguras dessa fracassada relação amorosa com Francisca Nogueira da Gama permaneceriam latejando na alma e no coração do "moço de talento", mas que, como se sabe, com o progressivo desenvolvimento de sua carreira literária, apesar do caráter sempre reservado em relação aos assuntos mais íntimos, seria ainda aclamado em vida. De todo modo, e levando em conta a conhecida e contumaz pré-disposição de Alencar para os embates, pois, como dissera Araripe Júnior, "não tolera sem protesto", há ainda dois curiosos textos no espólio alencariano - o fragmento de inconclusa crônica inédita ${ }^{12}$ e outro poema de seus dispersos - que, embora não se saiba as respectivas datas em que foram escritos, poderiam funcionar como providenciais fechos para essa história.

$\mathrm{Na}$ crônica interrompida, cujo simbólico título, de fundo mitológico, é "Pirausta", isto é, "mosca, da qual dizem que nasce do fogo, e vive no

\footnotetext{
${ }^{12}$ Agradeço ao incansável pesquisador alencariano, Marcelo Pellogio, da Universidade Federal do Ceará, que, gentilmente, disponibilizou-me uma cópia do manuscrito.
} 
fogo, e morre logo que sai dele" (BluTEAU; SILVA, 1789, p. 205), José de Alencar ${ }^{13}$ narra o encontro num baile de um jovem folhetinista - J. de Almeida" ${ }^{14}$ que frequentava os "salões da melhor sociedade [...], que havia adquirido certa reputação literária, [...] estreado na imprensa diária" e de "gênio pouco expansivo, timidez natural das almas modestas afastavam dele os que não o compreendiam", com uma "linda e graciosa menina que apenas saía da infância" e "filha de uma das maiores inteligências de nosso país". A jovem "com franqueza ingênua da inocência pediu a uma amiga que o apresentasse", uma vez que, "tinha lido os seus artigos; tinha sentido com eles; sorrira e palpitara as chispas do espírito, e as emoções que desenhara sua pena. Teve a curiosidade de conhecê-lo". Coincidentemente Francisca Nogueira da Gama tinha 14 anos quando conheceu o folhetinista José de Alencar. ${ }^{15}$

Se, pelo óbvio inacabamento da crônica, é impossível saber como terminaria a história ficcional, a metáfora do título talvez permita conjecturar que o suposto desenlace do amor não teria futuro, pois, $o$ "inseto", que nasce e, sobretudo, vive no "fogo", logo morre quando se afasta dele. Mas, além disso, é curioso perceber que, nas entrelinhas do texto, Alencar parece ter lançado mão de seus próprios caracteres para delinear os principais traços do jovem folhetinista, seja na sintomática escolha do nome, seja na caracterização do personagem, como atestam os primeiros parágrafos da crônica. Veja-se, nesse sentido, o fragmento inédito:

Encontrava-se habitualmente nos salões da melhor sociedade um moço, que havia adquirido certa reputação literária.

Tinha estreado na imprensa diária, primeiro estágio dos talentos jovens em nosso país, onde é necessário que a literatura e a ciência, para obterem um momento de atenção, se misturem no turbilhão diário das transações mercantis e dos acontecimentos políticos desta grande cidade.

Chamava-se J. de Almeida.

O moço, de quem então ignorava o nome, não tinha nada que excitasse a atenção: a não ser uma certa altivez brusca que o separava do meio da turba, dos grupos elegantes onde a conversa espirituosa animava a conversação. Gênio pouco expansivo, timidez natural das almas modestas afastavam dele os que não o compreendiam; e julgavam ver orgulho onde só havia isolamento.

$\mathrm{O}$ que ia ele fazer ao baile, ao teatro, às reuniões alegres e brilhantes, com a expressão de tédio que anuvia-lhe o semblante? Por que procurava a sociedade para isolar-se no meio dela, e

\footnotetext{
${ }^{13}$ Grifos nossos.

${ }^{14}$ Grifos nossos.

${ }^{15}$ Segundo informa Pedro Calmon: “Francisca - musa de José de Alencar - veio à luz [...], a 26 de maio de 1840" (CALMON, 1985, p. 46).
} 
percorrer com o olhar distraído a gente elegante que se divertia ao toque da música?

Era um filósofo, um observador, um namorado que procurava atordoar-se?

Não sei; o mundo o julgava pelo que parecia, como um indivíduo pouco simpático, orgulhoso em excesso, suportável apenas pelo seu talento, de trato insípido.

Uma noite, em uma pequena reunião de família, achava-se uma linda e graciosa menina que apenas saía da infância. Era filha de uma das maiores inteligências de nosso país; herdara um raio do fogo sagrado, e desde a sua infância aprendera a admirar em seu pai esse esplendor da luz divina.

Por acaso achava-se nessa reunião o escritor de que falei; a menina com franqueza ingênua da inocência pediu a uma amiga que o apresentasse. Tinha lido os seus artigos; tinha sentido com eles; sorrira e palpitara as chispas do espírito, e as emoções que desenhara sua pena. Teve a curiosidade de conhecê-lo.

Dos escritores de quem lera as obras, era o primeiro que via. Supôs, na sua ignorância, que um escritor era um homem diferente em tudo dos outros - falando só em versos; um livro vivo, abrindo as suas páginas brilhantes.

A sua amiga satisfez-lhe a curiosidade, e apresentou-lhe o moço. Ele respondeu ao sorriso que a menina lhe dirigiu com uma cortesia; moveu os lábios pronunciando uma palavra que não foi ouvida, e afastou-se como se houvera se despedido [em] vão.

A menina teve um despeito; mas as simpatias da infância são muito doces e puras para cederem à vaidade. $\mathrm{O}$ baile lembrava $\mathrm{a}$ crítica dos artigos; ela conservou a mesma [Aqui se interrompe o manuscrito]. (ALENCAR, [s/d])

Entretanto, se, no fragmento da crônica, por revelar caracteres íntimos que algo denunciavam a autoria do texto, a interpretação não permite ir além de meras conjecturas; no poema, com o sintomático título de "Desprezo", as coisas mudam de figura. Em outras palavras, o eu lírico alencariano se revolta contra o insulto de uma "nobre dama". E, com palavras duras, sentencia que não guardaria "Nem sombra [...] de tua imagem", acreditando que, a despeito de "Quando a ruga da face anunciar-te/ Da velhice os amargos desenganos", os versos em si, ainda assim, seriam lidos. Por isso, aumentando o tom incisivo do texto, reforçou a crença de que, quando o mundo procurar "algum vestígio/ Da mulher, que meus livros inspirava:", "Ninguém se lembrará nem do teu nome". Desse modo, como sabia que "O tempo não respeita a altiva fonte,/ A riqueza, o brasão, tudo consome:", a vingança final do eu lírico seria coroada com a explicitação de um mais que profundo desprezo, pois, no último verso, chancelaria: "Mulher, no meu desprezo eu dou-te a glória": 
Est'alma que insultaste se revolta!

Em sua viuvez, erma e vazia,

Nem sombra guardará de tua imagem;

Tanto amor que por ti ela sentia,

Não há de lhe arrancar nem mais um canto,

Que não seja apagado por meu pranto.

Como a flor a beleza em breve murcha:

A tua há de murchar em poucos anos;

Quando a ruga da face anunciar-te

Da velhice os amargos desenganos;

Quando de ti já todos esquecidos

Nem te olharem; meus versos serão lidos.

Talvez um dia o mundo caprichoso

Procure, nobre dama, algum vestígio

Da mulher que meus livros inspirava:

Não achará porém do teu fastígio

Senão traços de lágrima perdida,

Arcano de uma dor desconhecida.

O tempo não respeita a altiva fronte,

A riqueza, o brasão, tudo consome:

Um dia serás pó, e nada mais;

Ninguém se lembrará nem do teu nome.

Mas para que de ti reste a memória,

Mulher, no meu desprezo eu dou-te a glória.

(ALENCAR, 1960, p. 622-3)

Enfim, neste derradeiro poema, as referências à "riqueza" e ao "brasão", que são consumidos pelo tempo, poderiam muito bem sugerir que, ao escrevê-lo, José de Alencar talvez ainda estivesse pensando na jovem Francisca Calmon Nogueira Vale da Gama e nos consequentes sofrimentos amorosos que o atormentaram por imprecisos momentos. Ao fim e ao cabo dessa história de amor que não deu certo, tendo ou não a examada em mente, embora as circunstâncias apontem que sim, pode-se dizer que, vaticinado no próprio corpo do poema, o desejo de vingança literária do poeta Alencar contra aquela "nobre dama", de fato, aconteceu. 


\section{Referências bibliográficas}

AlENCAR, José de. Pirausta. [s/1]: [s/e], [s/d].

AlEnCAR, José de. Ao correr da pena. Organização de José Maria Vaz Pinto Coelho. São Paulo: Tipografia Alemã, 1874.

AlencAR, José de. Como e porque sou romancista. Rio de Janeiro: G. Leuzinger \& Filhos, 1893.

AlencAR, José de. Ao correr da pena. Organização de Francisco de Assis Barbosa. São Paulo: Melhoramentos, 1956.

AlENCAR, José de. Obra completa. Rio de Janeiro: Nova Aguilar, v. IV, 1960.

AlEnCAR, José de. Ao correr da pena. Organização de João Roberto Faria. São Paulo: Martins Fontes, 2004.

AlENCAR, José de. Ao correr da pena (folhetins inéditos). Estabelecimento de texto e introdução de Wilton José Marques. São Carlos: EDUFSCar, 2017.

ARARIPE JÚNIOR, Tristão de Alencar. Obra crítica de Araripe Júnior. Rio de Janeiro: Casa Rui Barbosa, v. 3, 1958.

AssIS, Machado de. Obra completa. Rio de Janeiro: Nova Aguilar, v. III, 1994.

Bluteau, Rafael; SILVA, Antonio de Morais. Dicionário de língua portuguesa. Lisboa: Oficina de Simão Tadeu Ferreira, v. 2, 1789.

CAlmon, Pedro. História de Minas e "memórias" de Nogueira da Gama. Rio de Janeiro: José Olympio; Brasília: INL, 1985.

CORREIO MERCANTIL. Rio de Janeiro, n. 75, 17 mar. 1855, p. 1.

DE MARCO, Valéria. O império da cortesã: Lucíola, um perfil de mulher. São Paulo: Martins Fontes, 1986.

GAMA, Visconde Nogueira da. Minhas memórias. Rio de Janeiro: Magalhães \& Comp. Editores, 1893.

GAZETA DE NOTÍCIAS. Rio de Janeiro. n. 354, p. 1, 23 dez. 1877

LYRA, Heitor. História de Dom Pedro II. São Paulo: Edusp; Belo Horizonte: Itatiaia, v. II, 1977.

MARTINS, Eduardo Vieira. Alencar e Nabuco. O eixo e a roda. Belo Horizonte, v.19, n. 2, p. 15-32, 2010.

MENEZES, Raimundo de. José de Alencar: literato e político. $2^{\mathrm{a}}$ ed. Rio de Janeiro: Livros Técnicos e Científicos, 1977.

NABUCO, Joaquim. Um estadista do Império. $5^{\text {a }}$ ed. Rio de Janeiro: Topbooks, v. II, 1997. 
Neto, Lira. O inimigo do rei: uma biografia de José de Alencar. São Paulo: Globo, 2006.

PINHO, Wanderley. Salões e Damas do Segundo Reinado. São Paulo: Martins, 1942.

VIANA FILHO, Luís. A vida de José de Alencar. São Paulo: Editora da UNESP; Salvador: EDUFBA, 2008.

Recebido em 27 de janeiro de 2021

Aprovado em 19 de agosto de 2021

Wilton José Marques é doutor em literatura brasileira pela Universidade de São Paulo. Professor titular de literatura brasileira e teoria literária do Departamento de Letras e do Programa de PósGraduação em Estudos de Literatura da Universidade Federal de São Carlos (UFSCar). Em 2011, recebeu o Prêmio Jabuti pelo livro Gonçalves Dias: o poeta na contramão (EDUFSCar, 2010). Posteriormente, publicou $O$ poeta do lá(EDUFSCar, 2014), O poeta sem livro e a pietà indígena (Editora da Unicamp, 2015), e, mais recentemente, Ao correr da pena (folhetins inéditos), de José de Alencar (EDUFSCar, 2017) e Leituras oitocentistas (EDUFSCar, 2019), coletânea, organizada com Franco Baptista Sandanello, em comemoração aos quinze anos do grupo de pesquisa Núcleo de Estudos Oitocentistas (NEO/UFSCar). Bolsista de produtividade do CNPq. Contato: will@ufscar.br

ORCiD: https://orcid.org/0000-0003-2559-9331 